\title{
原著
}

\section{吸収障害時のセロトニン，ヒスタミンの代謝，ならびに 両活性アミンの腸管運動への影響にかんする研究}

\author{
弘前大学医学部第一内科教室（指递 松永藤雄教授） \\ 三 戸 鉄 雄
}

\begin{abstract}
METABOLISM AND EFFECT ON_INTESTINAL MOTILITY OF SEROTONIN AND HISTAMINE IN THE MALABSORPTION STATE
\end{abstract}

Tetsuo SANNOHE

The First Department of Internal Medicine, Hirosaki University School of Medicine

(Director: Prof. Fujio Matsunaga)

概要 四収不良症候群のセロトニン代謝については, 種々の報告がある。一方, ヒスタミンは消化管 の運動，分泌，吸収関与すると考劣られている。しかし，その機序はまだ分に解明されていない． そこで著者は成犬40頭を用い，実驗的に広範囲飞小腸を切除して吸収不良状態をつくり，セロトニン ならびにヒスタミン代謝の変動，その腸管運動への影響および両者の関保等を倹討した。すなわち， 切除前および包除 1 カ月後の腸間膜静脈血, 小腸および大腸粘膜内のセロトニンとヒスタミンをFarrand蛍光分光々度計を用いて湘定した，その結果，実験的小腸切除による吸収不良状態では，腸間膜 静脈血セロトニン, ヒスタミンの産生は障害されないが，粘膜内セロトニン，上スタミンには代謝異 常がおこることおよびこの両フミンが腸管運動に強く関与していることを観察した。

\section{緒言}

セロトニン，ヒスタミンはそれを゙れトリプトフ フン，ヒスチヂンから生成される活性フミンであ り，生物に対してなんらかの生理作用を有する生 体内に存在する有機塩基化合物でるある ${ }^{1)}$.

セロトニンの主な存在場所は哺乳動物の胃腸粘 膜であつて，その粘膜内のenterochromaffine Zellenに由来寸る ${ }^{2}$ 。また，この粘膜内セロトニンは 腸管運動に関与する物質であるらといらことも，

これまでの研究で明らかにされてきている.

Massonは, argentaffine cell (enterochromaffine Zellen) が粘膜下神経叢の終末線維に解剖学的に 接近しているので，この細胞が腸管に神経内分泌 的役割をはたすと考㿠たる゙.

また，Haverbackは血中セロトニンは短時間の

[昭和 45 年 2 月 23 日受稿]
腸管運動え進を起こすが，細胞内セロトニンは 持続的腸管運動に与ると推察した ${ }^{5)}$.

吸収不良症候群のセロトニン代謝については，

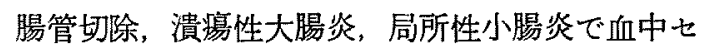
ロトニン扰よび尿中 5-hydroxyindol acetic acid (5-HIAA)が減少し, nontropical sprue, Whipple 病で増加すると報告されている5).

一方，ヒスタミンは消化管壁では胃から大腸粘 膜内にか子汁て最子多く存在し6)，肥満細胞性のる のと非肥満細胞性の二種類に分けられ，それらが 消化管の運動, 分泌, 吸収に関与するで方万うと 考えられている゙.

この二つの活性アミンの関係についてFeldberg はセロトニンにはヒスタミン遊離作用があると報 告している8?.

著者はイスを用い，実験的に広範囲に小腸を切 
除して吸収不良状熊をつくり，セロトニンならび にヒスタミン代謝の变動, その腸管運動への影響

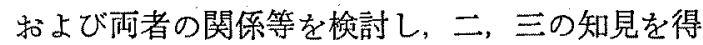
た。

\section{研究方法}

\section{1. 対象}

吸収不良障害犬の作製およびセロトニン。ヒス タミン測定用標本の採取

垁験動物は体重 $6.9 \sim 16.7 \mathrm{~kg}$ の成犬40頭を用 い, ラボナール静脈麻酔下に開腹して，切除子定 小腸間膜静脈より約 $10 \mathrm{ml}$ 採血し，七ロトニン測定 用にはヘパリンを加え，ヒ大タミン测定用には1 \%蓚酸ソーダを加えた。 その後，小腸を上部 $1 / 3$,

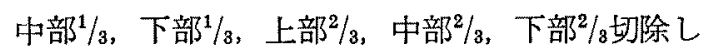
晹吻合を行なつた，切除した小腸から直らに粘膜

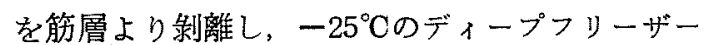
で凍結させ，七ロトニン招よびヒスタミンの測定 資料とした。

腸吻合犬は約 1 力月飼育後開腹し，門脈より採 血し，残存小腸和よび大腸を摘出し，上記と同様 にして測定に用いた。

2.七ロトニンならびにヒスタミン測定法

（1）血中七ロトニン量の測定

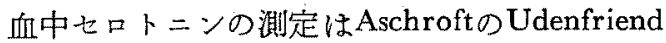
の変法"9ににたがい，図1のようにへパリン血 1 $\mathrm{ml}$ 亿水 $5 \mathrm{ml}$ 加兄て溶血させ，硫酸亜鉛乱よび 苛性ソーダで除蛋白 し，その上清 $4 \mathrm{ml}$ KV.Cを conc $\mathrm{HCl} 100 \mathrm{ml}$ 中に $50 \mathrm{mg}$ を含む $\mathrm{HCl} 2 \mathrm{ml}$ を加 兑，Farrand监光分光々度計を用いて行なつた。 监光波長を $550 \mathrm{~m} \mu$ 亿固定し，励起波長を 400

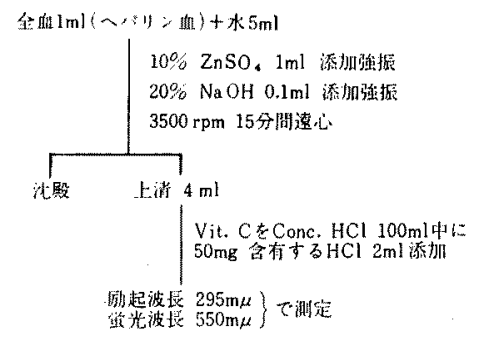

因 1.セロトニン抽出法

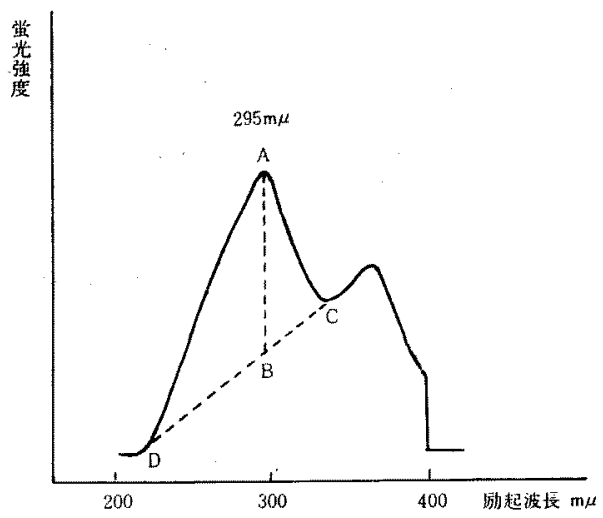

图2.七ロトニンの励起螢炎

$220 \mathrm{~m} \mu$ まで変化させて記録し，295m $\mu$ にみられ る頂点がセロトニンに特異的であるとし，図 2 の ようにA Bの長さをセ口トニンの蛍光量として定 量に用いた．この測定法の回収率は84.8\%で，そ の特異性については，セロトニン以外のインドー ル化合物の妨害を考慮しなければならないが，最 も妨害の多いと思われるトリプトファンについて す，その蛍光量はセロトニンの1/600であつたに 過ぎない，したがつてその妨害は極めて少ないと 考光られる．Farrand蛍光分光々度計は温度湿度 により不安定なため測定ごとにセロトニンクレア チニンサルフェイトを用い標準曲線を作成した。

（2）組織セロトニン量の測定

粘膜内セロトニンの測定はWeissbach ${ }^{10)}$ の方 法にしたがい，粘膜 $1 \mathrm{~g} に 0.1 N-\mathrm{HCl} 2 \mathrm{ml}$ を加 总，ホモゲナイザーで均質乳状化し，その上清 1 $\mathrm{ml}$ 上記Aschroft の方法で血液の場合と同様に行 なつた

（3）血中ヒスタミン量の測定

血中にスタミンはShoreら ${ }^{11} の$ 方法にしたがい， 図3のようにしてヒスタミンを抽出し，Farrand 蛍光分光々度計で測定した。萤光波長を $450 \mathrm{~m} \mu$ に固定し，励起波長を $400 \sim 300 \mathrm{~m} \mu$ まで变化さ せ，360m $\mu$ にられる頂点の高さをとスタミン の蛍光量として定量に用いた。標準曲線は測定每: に塩酸ヒスタミンを用いて作成した。 


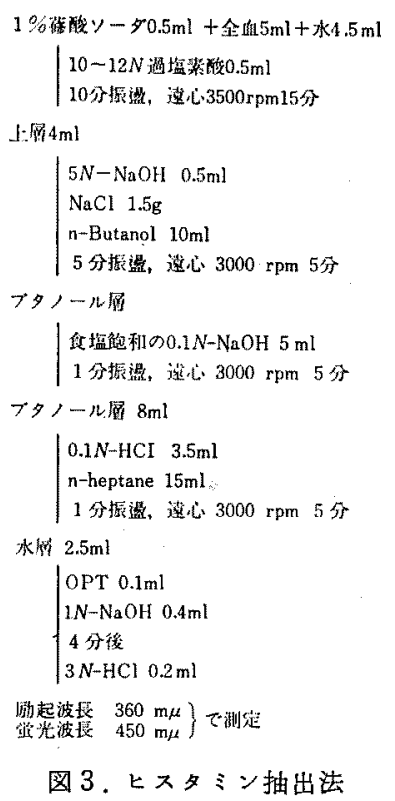

表 1 . 正常犬および実験的吸収障害犬の腸間膜髅脈 血, 小腸粘膜および大腸粘膜セロトニン值

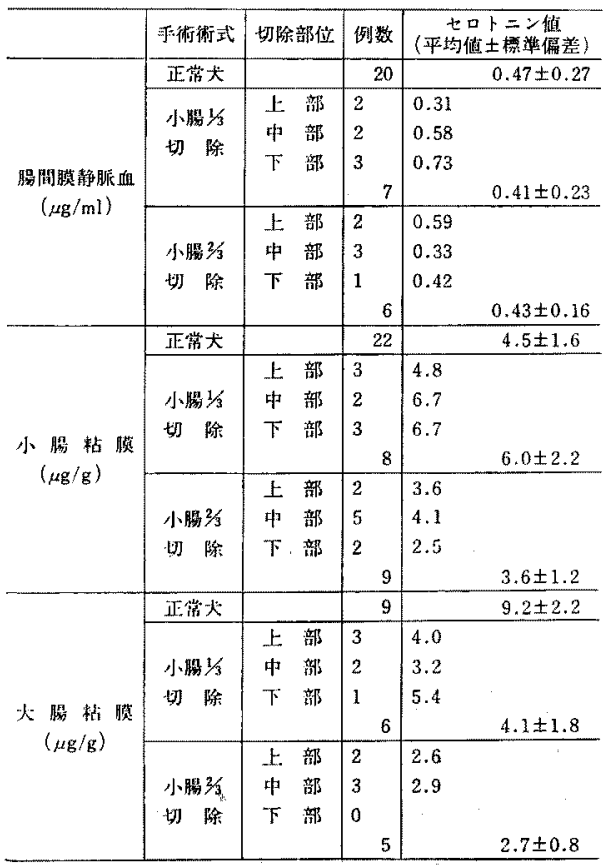

(4) 組穖ヒスタミンの測定

粘膜中ヒスタミンの測定はShore ${ }^{11)}$ の方法にし たがい，粘膜 $1 \mathrm{~g}$ に $0.4 N$ 過塩素酸 $9 \mathrm{ml}$ を加壳 ホモゲナイザーで均質乳状化し，遠心後その上清 $4 \mathrm{ml}$ をり以下血液の場合之同様に行なつた.

测定はすべて標本採取後24時間以内に行なわれ t.

\section{実験成績}

1.七ロトニン, ヒスタミンの変動（表 1 , 2)

（1）腸間膜静脈血セロトニンは正常犬（20 例)，小腸 $1 / 8$ 切除犬 ( 7 例)，小腸 $2 / 3$ 切除犬 ( 6 例)で， それぞれ $0.47 \pm 0.27 \mu \mathrm{g} / \mathrm{ml} ， 0.41 \pm 0.23 \mu \mathrm{g} / \mathrm{ml}$, $0.43 \pm 0.16 \mu \mathrm{g} / \mathrm{ml}$ であり，有意の差はなかつた（p $<0.05)$.

（2）小腸粘膜内セ口トニン正常犬（22例） 小腸 $1 / 8$ 切除犬 ( 8 例)，小腸 $2 / 3$ 切除犬 ( 9 例) で， それぞれ $4.5 \pm 1.6 \mu \mathrm{g} / \mathrm{g} ， 6.0 \pm 2.2 \mu \mathrm{g} / \mathrm{g}, 3.6 \pm$

表 2、正常犬おさび奏験的吸収障害犬の腸間膜静脈 血，小腸粘膜および大腸粘膜七スタミン值

\begin{tabular}{|c|c|c|c|c|}
\hline & 可街術式 & 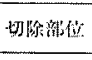 & 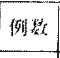 & 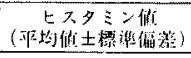 \\
\hline \multirow{3}{*}{ 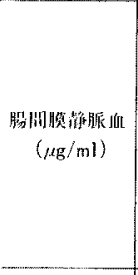 } & 正粪火 & & 30 & $0.116 \pm 0.060$ \\
\hline & $\begin{array}{l}\text { 小晹 } 1 / 3 \\
\text { 划 除 }\end{array}$ & 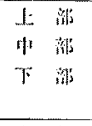 & $\begin{array}{ll}2 & \\
1 & \\
2 & \\
& 5\end{array}$ & $\begin{array}{l}0.285 \\
0.180 \\
0.110 \\
\quad 0.194 \pm 0.080\end{array}$ \\
\hline & $\begin{array}{l}\text { 小䏽2/3 } \\
\text { 切除 }\end{array}$ & 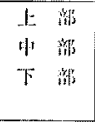 & $\begin{array}{|ll|}2 & \\
5 & \\
3 & \\
& 10 \\
\end{array}$ & $\begin{array}{l}0.205 \\
0.128 \\
0.139 \\
\quad 0.147 \pm 0.041\end{array}$ \\
\hline \multirow{3}{*}{$\begin{array}{c}\text { 小脂 } \text { 精 搭 }^{(\mu \mathrm{g} / \mathrm{g})}\end{array}$} & 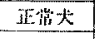 & & 18 & $32.6 \pm 10.3$ \\
\hline & 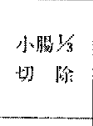 & 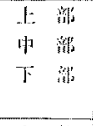 & $\begin{array}{l}3 \\
1\end{array}$ & .25131 .3 \\
\hline & $\begin{array}{l}\text { In } h_{0} 2 / 3 \\
\text { U) 除 }\end{array}$ & 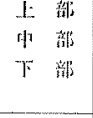 & $\begin{array}{cc}3 & \\
1 \\
3 \\
3 \\
10\end{array}$ & $33.2 \pm 1.4 .3$ \\
\hline \multirow{3}{*}{ 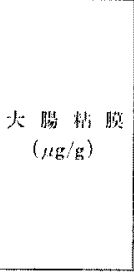 } & 正碾大 & & 7 & $5-.1 \pm 12.3$ \\
\hline & 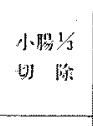 & 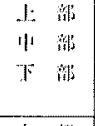 & $\begin{array}{ll}2 & \\
3 & \\
1 & \\
& 5 \\
\end{array}$ & $43.6 \pm 21,6$ \\
\hline & $\begin{array}{l}\text { 小晹 } 2 / 3 \\
\text { 期 }\end{array}$ & 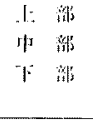 & $\begin{array}{ll}2 & \\
3 & \\
1 & \\
& 6\end{array}$ & $19.1 \pm 1.3 .2$ \\
\hline
\end{tabular}


$1.2 \mu \mathrm{g} / \mathrm{g}$ あ゙り, 有意の差はなかつた（ $\mathrm{p}<0.05 ）$.

（3）大腸粘膜内七ロトニンは正常犬（9例), 小腸 $1 / 8$ 切除犬 ( 6 例)，小腸 $2 / 3$ 切除犬 ( 5 例) で, それぞれ $9.2 \pm 2.2 \mu \mathrm{g} / \mathrm{g} ， 4.1 \pm 1.8 \mu \mathrm{g} / \mathrm{g}, 2.7 \pm$ $0.8 \mu \mathrm{g} / \mathrm{g}$ であり，切除犬では正常犬に比して有意 の減少があつた $(\mathrm{p}<0.01)$.

（4）腸間膜静脈血ヒスタミンは正常犬（20 例)，小腸 $1 / 3$ 切除犬( 5 例)，小腸 $2 / 8$ 切除犬(10例)で, それぞれ $0.116 \pm 0.060 \mu \mathrm{g} / \mathrm{ml}, 0.194 \pm 0.080 \mu \mathrm{g} /$ $\mathrm{ml}, 0.147 \pm 0.041 \mu \mathrm{g} / \mathrm{ml}$ です，有意の差はなか つた $(\mathrm{p}<0.05)$.

（5）小腸粘膜内ヒスタミンは正常犬（18例)， 小腸 $1 / 8$ 切除大 ( 4 例), 小腸 $2 / 8$ 切除犬 (10例)で，そ れぞれ $32.6 \pm 10.3 \mu \mathrm{g} / \mathrm{g}, 25.3 \pm 31.3 \mu \mathrm{g} / \mathrm{g}, 33.2 \pm$ $14.3 \mu \mathrm{g} / \mathrm{g}$ であり，有意の差はなかつた（p<0.05）.

（6）大腸粘膜内七スタミンは正常犬（7 例）

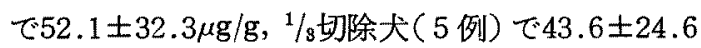
$\mu \mathrm{g} / \mathrm{g}$ 之減少がみられるが有意の差はない（p< 0.05). しかし， $2 / 3$ 切除犬（6例）では19.1土13.2 $\mu \mathrm{g} / \mathrm{g}$ と有意の減少（p<0.01）があつた.

2. 七ロトニンとヒスタミンの関係

（1）正常犬腸間膜静脈血中七ロトニンとヒス タミンの間には有意の相関 $(r=-0.239)$ はなか つた $(\mathrm{p}<0.05)$ (図 4$)$.

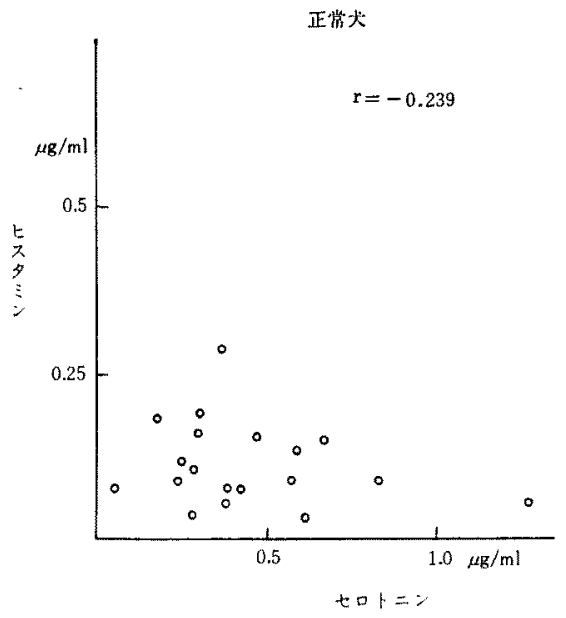

図 4.腸間膜静眽血中の七ロトニンとヒスタミン

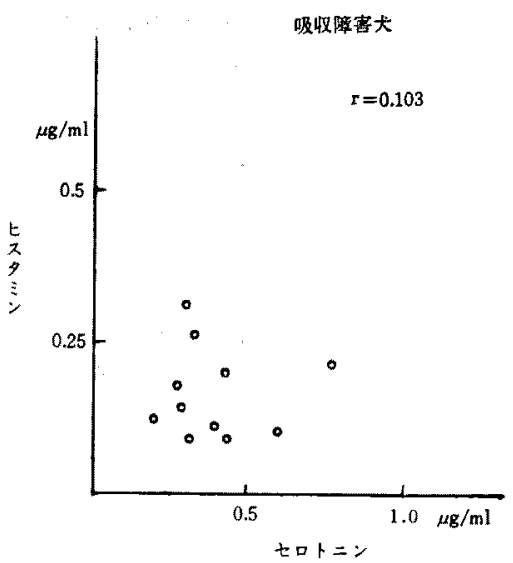

因 5.腸間膜静脈血中のセロトニンとヒスタミン

正常犬

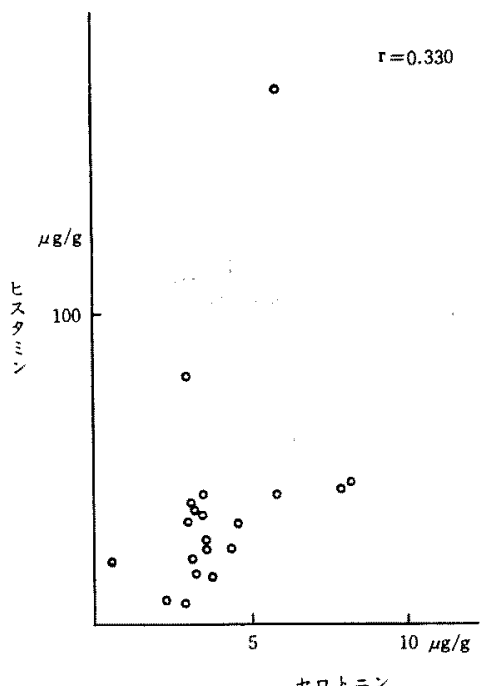

図6、小腸粘膜のセロトニンとヒスタミン

（2）吸収障害犬の腸間膜静脈血中七口トニン とヒスタミンの間には有意の相関 $(r=0.103)$ はなかつた $(p<0.05$ )(図 5 ).

（3）正常犬小腸粘膜内七ロトニンとヒスタ ミ ンの間には有意の相関 $(r=0.330)$ はなかつた $(\mathrm{p}<0.05)$ (図 6 ).

（4）吸収障害犬の小腸粘膜内七ロトニンとヒ スタミンの間には有意の正の相関 $(r=0.582)$ があつた $(\mathrm{p}<0.05)$ (図 7$)$. 


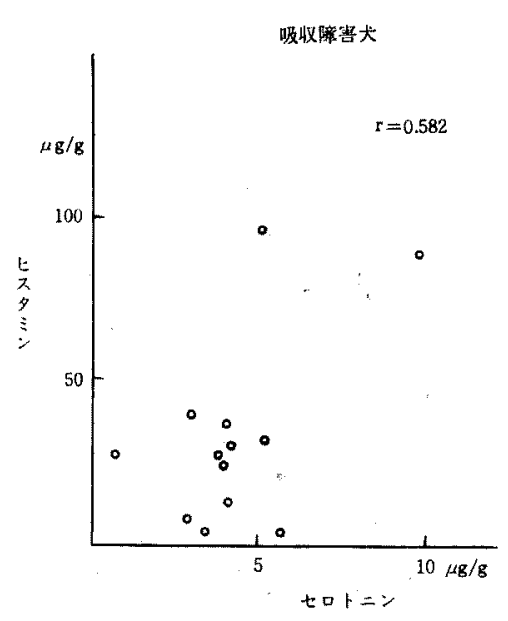

図 7.小腸粘膜のセロトニンとヒスタミン

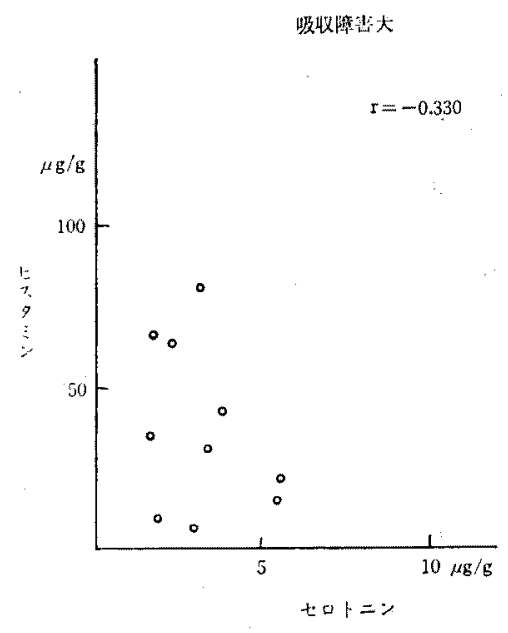

図 8.大腸粘膜のセロトニンとヒスタミン

（5）吸収障害犬の大腸粘膜内セロトニンとヒ スタミンの間には有意の相関 $(\mathbf{r}=-0.330)$ は なかつた $(\mathrm{p}<0.05)($ 図 8$)$.

\section{考 案}

1.七ロトニンならびにヒスタミン代謝

イスの小腸および大腸粘膜七ロトニン含有量

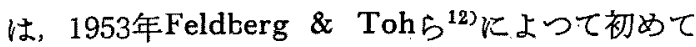
報告されたが，著者の測定した正常犬での值はこ れとほぼ等しく，また，腸間膜静脈血七ロトニン 量は橴沢の報告とほ注等しい。

吸取不良症候群に和けるセロトニン代謝につい
ての研究は1958年Haverbackら5)の報告にはじま る. 彼らは，人間の広範囲腸切除者では末梢血七 ロトニンが著減することや，潰瘍性大腸炎，局所 性小腸炎ではセロトニンの最終代謝産物である 5-HIAAが比較的少ないことを観察し，この事実 はセロトニンが腸管と関連ある物質であるといら 説を裏付けるるのであると述べている，一方，吸 収不良症候群を示すnontropical sprueやWhipple 病では尿中の5-HIAAが増加するという報告が Haverback (1958, 1960) ${ }^{576)}$, Kowlessar (1958), Pimpaker (1961), Warner (1962) らによりなさ れている。しかし，このトリプトファンの代謝 異常の×カニズムは充分飞解明されてはいない。 著者の実験的吸収不良状態飞和ける晹間膜静脈血 セロトニンは，正常時に比し有意の変動はなから た.このことは残存小腸でのトリブトフォンの吸 収が正常なのか，または，吸収された少ないトリ ブトファンのセロトニン合成への利用の相対的増 加によるものと考克ら机る. そしてこの生物学的 意義は充分に説明しえないが，生体にとつて生理 作用を有するこのアミンを正常時と同様に保たし めんとする生体のホメオスタージスの現象と考え られる。

次に，この実験的吸収不良状態における粘膜 内七ロトニンの変動は，以下に述べる諸家の報告 とも考光併せ，腸管の運動と密接な関俰にあるあ のと思われる.1930年Masson( ${ }^{82}$ ， argentaffine cell は粘膜下神経謭の終末線維に解剖学的に接近 している事実から，この細胞が粘膜下神経證に神 経内分泌的な役割をはたすのではないかと考党 た. Haverback ${ }^{5}$ は，血中にセロトニンを継絸的 に注入する場合；腸管の反応は最初に一時的にみ られるだけであるのに反し，七口トニンの前駆物 質である5-hydroxytryptophanの 注入では持続的 な反応があることから，腸管運動は細胞内セ口卜 ニンの効果によるるのと推定した。. Bülbring ${ }^{13)}$ セロトニンは蠕動反射を䒩き起こす粘膜中の感覚 受容体に刺激を与光，したがつて腸管粘膜内での セロトニンの生成は蠕動運動のために必要な生理 
表 3 、実験的小腸切除犬の上行結腸笳電図

\begin{tabular}{|c|c|c|c|c|}
\hline & スバイク数 & 壥 & 放電閒秀 \\
\hline \multicolumn{2}{|c|}{ 正常火 } & $8 \sim 12$ & $89-411 \mu \mathrm{V}$ & $5.6 \sim 7.6$ 科 \\
\hline \multirow{3}{*}{ 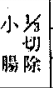 } & 上部 & $1 \sim 2$ & $250-320$ & 6.8 \\
\hline & 中部 & $1 \sim 2$ & $89 \sim 143$ & $4.8 \sim 5.6$ \\
\hline & 下部 & 1 & $54-89$ & 页 规 㭢 \\
\hline \multirow{2}{*}{ 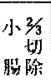 } & 上部 & 1 & 162 & 不 规 \\
\hline & T部 & 㱛とみられず & 殆とみられす & 如 烧 \\
\hline
\end{tabular}

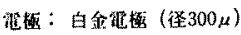

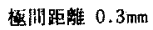
都留抵抗 $70 \mathrm{k} \Omega$ 以下 澋定数: 0.03

校正桶稳: $500 \mathrm{\mu V}$

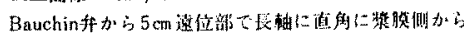

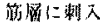

的機構であろうと述べている.

Silvaら ${ }^{14)}$ は，七ロトニンは回腸壁内の神経組 織の副交感神経節後線維に作用すると述へ，Hendrix ${ }^{15)}$ せロトニンはコリン作動性神経をと扎し て腸管運動の活動に刺激を与えると述べている。 最近ではGershonら ${ }^{16)}$ は粘膜外腸管筋層神経叢に も少量ながらセロトニンがありこのセロトニン はアセチルコリン様に作用し，腸管運動に抑制的 に作用寸る腸管壁在神経節細胞を刺激する神経刺 激伝達物質であると述べている。

著者の実験では，小腸切除犬の大腸粘膜内セ口 トニンは正常時にくらべ著减し，小腸 $1 / 3$ 切除， $2 / 8$ 切除々切除範囲が大きい程減少が著しい。また， 著者と共同で実験を行なつた小野ら ${ }^{17)}$ は, $1 / 3$ 切除 犬では小腸の上，中，下部のいずれを切除した場 合でも右側結腸の放電活動が非切除犬のそ礼に較 べ著明に抑制され，2/3切除犬では一層著明に抑制 されることを観察している（表３）.

このようにセロトニンが粘膜内で減少するのに したがい，腸管運動は強く抑制される．このこと は腸管切除による吸収不良状態においては，大腸 内容物の急激な排出を防ぎ，移送時間を荤らしめ ようとするホメオスタージスの現象と考えられ る.一方，小腸粘膜内のセロトニン量は正常時に 変りないが，このことも吸収不良状態において腸 管運動を正常に保ち，吸収を良くしょうとする生 体のホメオスタージスと考克られる.このよらに 広範囲小腸切除による吸収不良状態では，同一生
体内の消化管である小腸と大腸においても合目的 的にセロトニンの代謝は著しく異なる。

腸管切除後の吸収不良症候群におけるヒスタミ ンの代謝についてはすまり報告がない。

しかし，イヌの消化管壁内ヒスタミンについて

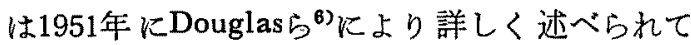
いる，彼らによると，ヒスタミンは消化管のどの 部位でも大部分が粘膜内にあるが，特に粘膜筋層 で活性が高い。この部位には神経終末線維や粘 膜下神経叢の神経細胞が存在して和り，腸管分泌 への生理的刺激物質となつていると考えられてい る. - Feldberg ${ }^{18)}$ によるとイ 邓の粘膜内ヒスタミン 量は胃から大腸にかけて次第に減少するが，著 者の成績では大腸の方が小腸より高い傾向にあっ た。

消化管には 2 種類のヒスタミンが存在しひと つは肥満細胞内のものであり，他は粘膜内のもの である7゙. 消化管の肥満細胞は胃から直腸にかけ て存在し，その数は研究者により種々であるが， これらの肥満細胞が消化管粘膜内に多数存在する ことは，肥満細胞内ヒスタミンが非肥満細胞七ス タミンとともに消化管の機能に関与するのである う.このように粘膜内ヒスタミンの腸管への関与 そ考皇ると，著者の実験に括ける残存小腸粘膜内 ヒスタミンは正常に保たれ，小腸 $2 / 3$ 切除犬大腸粘 膜内ヒスタミンの減少は上記セロトニンと同様に 小腸の運動, 吸取, 分泌を正常に保持し, 一方, 大腸に执いてはその運動を抑制しようとするホメ オスタージスの現象と考えられる。

しかるに，腸間膜静脈血ヒスタミンはこのよう な吸収不良状態に拉いても，七ロトニンと同様に その産生は障害されない. $1 / 3$ 切除犬では有意の增 加があるが，このような吸取不良状態では生理的 に活性であるヒスタミンの増加を生体が必要とす ることも推測される.

2. セロトニンとヒスタミンの関保

セロトニンはヒスタミンリベレーターであると いわれている。すなわち，Feldberg" Imtoshが1949年に初めてアミンはヒスタミン遊離 
表 4.七ロトニン注射前後の腸間膜静脈血ヒス タミン值

\begin{tabular}{|c|c|c|c|}
\hline & 七ロトニン & \multicolumn{2}{|c|}{ ヒスタミン 俩 $\mu \mathrm{g} / \mathrm{ml}$} \\
\hline & 拄射 证 & 拄射 iif & 隹射後 \\
\hline Dog 1 & $1.5 \mathrm{mg}$ & 0.084 & 0.171 \\
\hline Dog 2 & $3.5 \mathrm{mg}$ & 0.055 & 0.079 \\
\hline Dog 3 & $4.0 \mathrm{mg}$ & 0.018 & 0.033 \\
\hline $\operatorname{Dog} 4$ & $10.0 \mathrm{mg}$ & 0.039 & 0.072 \\
\hline
\end{tabular}

物質であると報告し，彼自身も七ロトニンは組織 内ヒスタミンを遊離することを説明した. Pernow ${ }^{19}$ はヒスタミン，セロトニンの両者が血中 和よび尿中に増加するカルチノイドージスを報告 し, セロトニンの増加がヒスタミンを二次的に遊 離するのであろうと説明した。

著者の実験では，イヌの腸管膜静脈血で正常状 態技よび吸収不良状態において，両アミンに量的 相関々係はみられないが，セロトニンを大量に静 注した場合には腸間膜静脈血ヒスタミンの軽度の 増加があつた（表 4).このことから急激にしかむ 大量の七ロトニンが血中に遊離された場合に初め てヒスタミンの血中遊離が惹起されるものと考え られる。

小腸粘膜では，正常状態では相関がないが，吸 収不良状態では有意の相関がある.大腸粘膜では 吸収不良状態での検索で相関がなかつた．Doug$\operatorname{las}^{6}$ ) は胃粘膜内での両者の存在は非常に良く似て いることを報告しているが，著者の実験では一定 の傾向がみられなかつた。

3. セロトニンならびにヒスタミンの腸管運動 への影響

成犬10頭を用い，ラボナールで麻酔後開腹し，

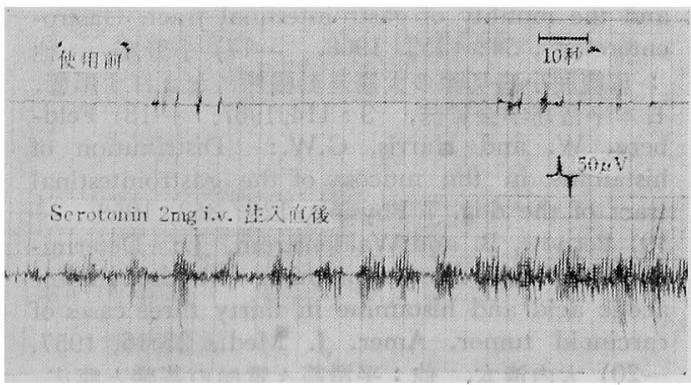

図 9,Serotonin使用前後の正常犬大腸笳電図

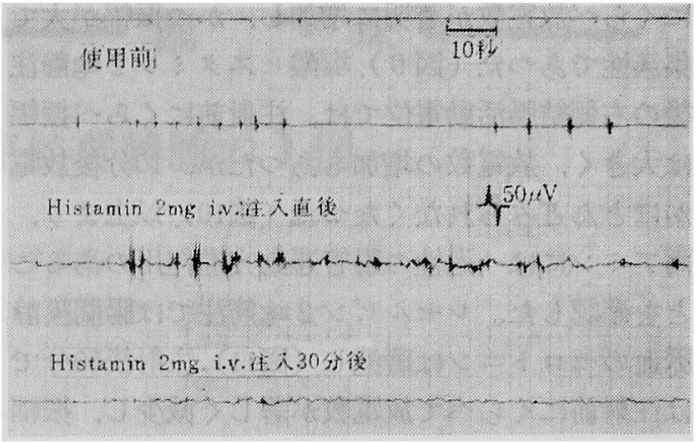

図10.Histamin使用前後の正常犬大腸筋電図

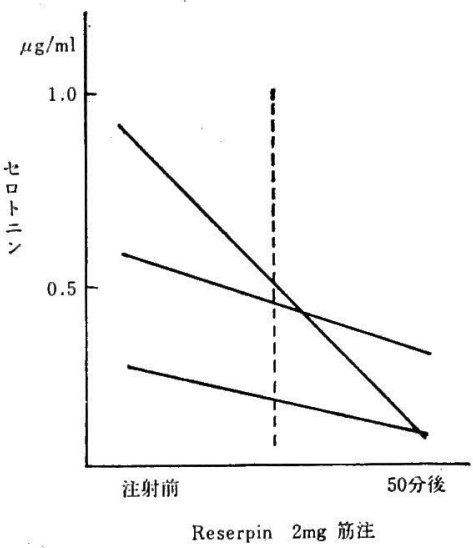

図11、レセルピン注射前後の腸間膜静脈血セロ ト ニン值

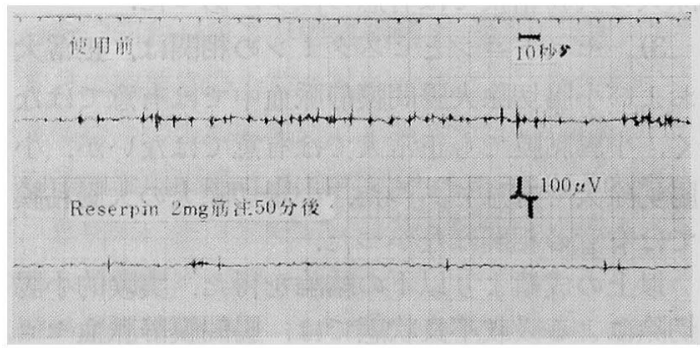

図12，Reserpin使用前後の正常犬大腸筋電図

右側結腸の浆膜側から，大内ら ${ }^{20)}$ の方法にしたが い径 $300 \mu$ の白金双極植込電極（極間距離 $1 \mathrm{~mm}$ ) を刺入後縫着固定し，セロトニンクレアチニンサ ルフェイト招よび塩酸ヒ大タミンの静脈注射前後 の活動電位をそれぞれ記録した．その結果，セ口 トニン $2 \mathrm{mg}$ 静注後の右側結腸活動電位は, 注射前 
にくらべ放電数が著明に増加し，かつ振幅が大で 集簇性であつた（図9). 塩酸ヒスタミン $2 \mathrm{mg}$ 静注 後の右側結腸活動電位では, 注射前にくらべ振幅 は大きく，放電数の増加むあつたが，10分後放電 がほとんどみられなくなっ（図10).以上より， 両アミンには一過性の腸管運動六進作用のあるこ とを確認した.レセルピン $2 \mathrm{mg}$ 筋注では晹間膜静 脈血のセロトニンは著減し（図11）,注射後50分で は注射前にくらべて放電数が著しく減少し，振幅 む小さくなつた（図12）。このとはセロトニンと 腸管運動の関係を良く表わしていると思う。

\section{結 論}

イヌの小腸を広範囲に切除して吸収不良状態を つくり，切除前扣よび切除 1 力月後の晹間膜静脈 血, 小腸扎よび大腸粘膜内のセロトニンとヒスタ ミンを測定し，次のごとき結果を得た。

1）小腸切除犬のセロトニンは，腸間膜静脈血 牤よび小腸粘膜では有意の変動はないが，大腸粘 膜では有意の娍少があつた。

2）小腸切除犬のヒスタミンは腸間膜静脈血で は，1/3切除では有意の上昇があるが，2/3切除では 有意の変動がなかつた．また，小腸粘膜では $1 / 3$, $2 / 3$ 切除ともに有意の变動がなく，大腸粘膜でも， $1 / 3$ 切除では有意の变動がなかつた. しかし， $2 / 3$ 七刀 除犬の大腸粘膜では有意の減少があつた。

3）セロトニンとヒスタミンの相関は, 正常犬 特よび小腸切除犬腸間膜静脈血中では有意ではな く，小腸粘膜でも正常犬では有意ではないが，小 腸切除犬で有意であつた，小腸切除犬の大腸粘膜 では有意の相関はなかつた。

以上の成績より以下の結論を得た，実験的小腸

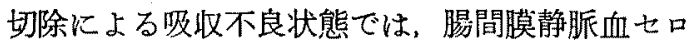
トニン，ヒスタミンの産生は障害されないが，粘 膜内セロトニン，ヒスタミンには代謝異常がおこ る.またこの両アミンが腸管運動に強く関与し ていることを観察した.

\section{文献}

1) 村田敏郎：活性〉ミンの代謝之生物学的意義(総 諭的). 代謝, $3: 698,1966$. - - 2) Erspamer, V. and Assero, B.: Identification of enteramin, specific hormone of enterochromaffin cell system, a 5-hydroxytryptamin. Nature (London), 169: 800, 1952. -3) Masson, P.: The significance of the muscular stroma of argentaffine tumors (carcinoidosis). Amer. J. Path., 6: 466, 1930. -4) Haverback, B.J., Hogen, A.M., Moran, N.C. and Luther, L. T.: Effect of serotonin (5-hydroxytryptamine) and related compounds on gastric secretion and intestinal motility in the dog. Gastroenterology, 32: 1058, 1957. -5) Haverback, B.J. and Davidson, J.O.: Serotonin and the gastroentestinaltract. Gastroenterology, 36: 570, $1958 .-6$ ) Douglas, W.W., Fe!dberg, W., Paton, W.D.M. and Schachter, M.: Distribution of histamine and substance $P$ in the wall of dog's digestive tract. J. Physiol., 115: 163, 1951. - 7) Sommers, S.C.: Mast cells and paneth cells in ulcerative colitis. Discussion of paper presented by Dr. Sommers. Gastroenterology, 51: 848, $1966 .-8$ ) Feldberg, W. and Smith, A.N.: Release of histamine by tryptamine and 5-hydroxytryptamine. Brit. J. Pharmacol., 8: 406, 1953. -9) Aschroft, G.W. and Crawford, T.B.B.: Estimation of 5-hydroxytryptamine in the human blood. Clinica Chimica Acta, 9: 364, 1964. -10) Weissbach, H., Waalkes, T.P. and Undenfriend, S.: A simplified method for measuring serotonin in tissue; simultaneous assay of both serotonin and histamine, J. Biol. Chem., 230: 865, 1957. -11) Shore, P.A., Barkhalter, A. and Cohn, V.H.: A method for the fluorometric assay of histamine in tissue. J. Pharmacol. Exp. Ther., 127: 182, 1959. -12) Feldberg, W. and Toh, C.C.: Distribution of 5-hydroxytryptamine in the wall of the digestive tract. J. Physiol., 119: 352, 1953. -13) Bülbring, E. and Lin, R.C.Y.: The action of 5-hydroxytryptamine $(5 \mathrm{HT})$ on peristalsis. J. Physiol., 138: 121, 1967. -14) Silva, M.R. E., Valle, J.R. and Picarelli, Z.P.: A phamacological analysis of the mode of action of serotonin (5-hydroxytryptamine) upon the guinea-pig ileum. Brit. J. Pharmacol., 8: 378, $1956 . \quad-15)$ Hedrix, T.R., Atkinson, M., Clifton, J.A. and Ingelfinger, F.J.: The effect of 5-HT on intestinal motor function in man. Amer. J. Med., 23: 886, 1957. -16) Gershon, M.D.: Serotonin and the motility of gastrointestinal tract. Gastroenterology, 54: 453，1968. -17) 小野庭一, 他

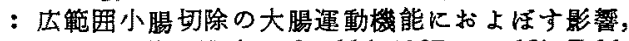
日本平滑筋学会雜誌, $3: 114,1967$, - 18) Feldberg, W. and Harris, G.W.: Distribution of histamine in the mucosa of the gastrointestinal tract of the dog. J. Physiol., 120: 352, 1953 . 19) Pernow, B. and Waldenström, J.: Determination of 5-hydroxytryptamine, 5-hydroxyindole acetic acid and histamine in thirty three cases of carcinoid tumor. Amer. J. Med., 23:16, 1957.

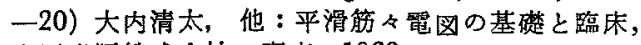
金原出版株式会社, 東京, 1966. 